\title{
Effects of Delegated Water Provisioning on Quality of Drinking Water in Low Income Areas of Kisumu County, Kenya
}

\author{
Mosota Ben* \\ School of Nursing, Midwifery\& Paramedical Sciences, \\ Masinde Muliro University of Science \& Technology, P.O.Box 190-50100, Kakamega, Kenya \\ Dr. Damaris Ochanda, \\ School of Nursing, Midwifery\& Paramedical Sciences, \\ Masinde Muliro University of Science \& Technology, P.O.Box 190-50100, Kakamega, Kenya \\ Akosua Sarpong Boakye-Ansah \\ UNESCO-IHE Institute for Water Education, Westvest 7, 2611 AX Delft, The Netherlands
}

\begin{abstract}
Only $62 \%$ of the African population have access to improved water supply. In Kenya $14 \%$ of the households in the urban areas, are privately connected to improved water supply systems. However, intermittent water supply has been reported to be a constant constraint in most low income areas in Kenya, making the residents of these areas to seek for alternative water sources such as water cart vendors, with exorbitant water prices and questionable water quality. Intermittent water supply increases the risk of water contamination through breaks and leaks leading to life threatening waterborne diseases. Delegated Management Model was adopted by water utilities in developing countries to address water access and quality issues in low income areas in developing countries. The aim of the study was to investigate the impact of DMM on the quality of drinking water in low-income areas of Kisumu County in Kenya. A descriptive cross-sectional research design was adopted. A total of 80 water samples were collected with 56 collected at the water kiosks while 24 were collected from the households. A two-sample t-test was used to determine if the differences in quality of the drinking water from the two settlements was significant at $95 \%$ confidence interval and $\mathrm{p}$ value set at .05 . The study findings at the point of supply (water kiosks), indicated that, only the PH was within the WHO recommended standards. Turbidity, residual chlorine, total coliforms and Faecal Coliforms were all above the WHO recommended levels, and were statistically significant at $p<0.05$. At the household, turbidity (NTU $>1$ ), total Coliforms and faecal Coliforms were all above the WHO standards. Both turbidity, total and faecal coliforms recorded significant decrease at $\mathrm{p}<0.05$ though the parameters were still not within the WHO recommended levels. Though the DMM model of water supply in Nyalenda and Manyatta has improved access to water in the two informal settlement areas, findings show alterations in water quality parameters both at the water kiosks and at the household level which indicates contamination in the water supply. The study therefore recommends closer water quality monitoring at the Supply points (water kiosks) and at the households to identify and prevent sources of contamination. Further, health education strategies should be put in place to enhance proper water handling and storage among the residents. Further research should be done to identify the source of contamination.
\end{abstract}

Keywords: Water, Drinking water, Water quality, Water Provisioning, low income areas

DOI: $10.7176 / \mathrm{JHMN} / 60-12$

Publication date:March $31^{\text {st }} 2019$

\section{Introduction}

According to the global water supply and sanitation assessment report, Africa has the lowest water supply coverage than any other region, with only $62 \%$ of the population accessing improved water supply (WHO,UNICEF, 2000). Furthermore, the situation in the rural areas in Africa is even worse as only $47 \%$ gets access to improved water supply. In rapidly growing population in the urban centers, as an outcome of migration from rural to urban areas, the magnitude of the water supply problem is anticipated to rise as the urban areas will not be having enough resources to accommodate the influx of more people (WHO,UNICEF, 2012).

According to the Kenya Open data project report, it is reported that merely $14 \%$ of the Kenyan households in the urban areas, are privately connected to improved water supply (Kenya Open Data Project, 2012). However, intermittent water supply has been reported to be a constant constraint in most low income areas in Kenya, making the residents of this areas to seek for alternative water sources such as water cart vendors, with exorbitant water prices and questionable water quality. The intermittent water supply (Geldreich \& Kumpel \& Nelson, 2011), increases the risk of intrusion by contaminated water into the water pipelines through breaks and leaks (WHO,UNICEF, 2000). Furthermore, it's important to note that complications that come about as a result of waterborne diseases, arising from contaminated water, are life threatening (UN Reuters, 2016). According to UNEP report, more people in the world are affected by contaminated water than expected (United Nations 
Enviroment Program, 2015).

Citizen Report Card (2007), indicates that a good number of Kenyan citizens living in the poor urban areas, access contaminated water that puts them at a risk of water borne diseases that are detrimental to health (Willems $\&$ McDonald, 2011). In order to improve access to quality water in low income areas (LIAs), water utilities in developing countries came up with various innovative approaches and models. One of such models is the Delegated Management Model (DMM), where water utilities delegate the supply and sale of water in LIAs to groups and individuals living in these communities. This approach provide utilities with an opportunity to partner with community-based organisations (CBOs) and individuals / entrepreneurs to enhance access to water to the growing low-income consumers. The DMM is in use in Kotei, a LIA in Ghana and also in Kisumu, Kenya (WSP Water and Sanitation Program, 2009).

The introduction of the DMM in Kisumu was expected to address problems related to access to water in the LIA's. In line with this assertion, a considerable number of studies have been conducted on water access in LIA's. Similar studies revealed that few households in these areas access water for their daily needs, with each household giving their version on the same. Further, households depend on other water sources such as water kiosks (Wagah, Onyango, \& Kibwage, 2010).

Studies in the low income areas, noted that only $10 \%$ of the households in LIAs could access piped water (Nodalis Conseil, 2014). Limited literature exist on how the DMM has impacts water quality, and the health of the LIA consumer in Africa other than the Lilongwe, Malawi study which looked into the quality of water supplied to the residents of low income settlements (Boakye-Ansah, 2015). This is a gap that this research sought to fill by assessing the quality of water at the supply points (water Kiosks) and in households in the LIA supplied through the DMM model.

\section{Methods}

This study was carried out in the low income areas of Nyalenda and Manyatta, in Kisumu County, Kenya. The 2009 Kenya Census indicates that the county which is at the banks of Lake Victoria has a population of nearly one million. A descriptive cross-sectional research design was adopted and data was collected using quantitative methods. The study areas were selected due to their connectivity to the main water line and the availability of the water kiosks supplying water to the residents of these areas through the DMM water supply model. In this study, 80 water samples were collected for water analysis. Out of these, 56 samples were collected from water supply points (water kiosks) while 24 were collected from the households. The study was conducted between FebruaryApril 2018. Systematic sampling was used for selecting households and water kiosks where the water samples were drawn. Water samples from the kiosks and in houses with tap connections were collected after allowing the water to run for 2-3 minutes. Samples from households in stored water containers were poured directly from the storage containers used by the residents into the sterile bottles. Water temperature and $\mathrm{pH}$ was checked immediately after collection; the rest of the parameters were analyzed at the laboratory. The samples were then kept in insulated cooler boxes containing ice packs and transported to the laboratory where they were then processed and analyzed. Incubation was done for the fecal and total coliforms for 24 hours

Data was coded and analyzed using SPSS version 20.0. Selected physicochemical and microbiological parameters of Turbidity, residual chlorine, temperature, Fecal Coliforms and total coliforms analyses were carried out and compared with the WHO set levels. Descriptive statistics of frequency, mean, percentages and standard deviation were also used for data analysis.

\section{Results}

This study investigated the water quality using microbiological and physico-chemical parameters which were measured against WHO guidelines as shown in table 1.

\subsection{Quality of drinking water at the points of supply \\ 3.1.1 Microbiology}

The findings on water quality at points of supply give an indication of fecal contamination and the possible presence of other pathogens. In Nyalenda kiosks, the mean values observed for the fecal coliforms was 250.97 CFU/100mls $(S D=1560.65)$ while in Manyatta the mean value observed at the Kiosks was $6.00 \mathrm{CFU} / 100 \mathrm{mls}$ ( $S D$ $=5.16$ ). The secondary data obtained from the water utility's laboratory, from 2004-2007, indicated that the fecal coliforms in Nyalenda Kiosks had a mean of $215.25 \mathrm{CFU} / 100 \mathrm{mls}(S D=1442.4)$ while Manyatta Kiosks had a mean value of $402.75 \mathrm{CFU} / 100 \mathrm{mls}(S D=1634.2)$. Total coliforms for the same period were $729.54 \pm 2594.4$ and 1097.2 for Nyalenda and Manyatta respectively. 
Table 1: Quality of drinking water at points of supply

\begin{tabular}{|c|c|c|c|c|c|c|c|}
\hline 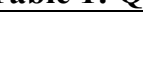 & $\begin{array}{c}\text { Number } \\
\text { of }\end{array}$ & pH & Temperature & Turbidity & $\begin{array}{l}\text { Residual } \\
\text { chlorine }\end{array}$ & $\begin{array}{c}\text { Faecal. } \\
\text { Coliforms }\end{array}$ & Total coliforms \\
\hline Units & samples & & ${ }^{0} \mathrm{C}$ & NTU & $\mathrm{mg} / \mathrm{L}$ & CFU/100 mL & CFU/100 mL \\
\hline $\begin{array}{l}\text { WHO } \\
\text { value }\end{array}$ & & $6.5-8.5$ & $25^{0} \mathrm{C}-30^{0} \mathrm{C}$ & 1 & 0.2 & 0 & 0 \\
\hline \multicolumn{8}{|c|}{ Water Kiosk's samples } \\
\hline Nyalenda & 49 & $7.31+0.33$ & $26.30 \pm 1.72$ & $3.17 \pm 1.84$ & $0.34 \pm 0.18$ & $250.97 \pm 1560.64$ & $830.61 \pm 2762.64$ \\
\hline Manyatta & 7 & $7.19 \pm 0.04$ & $26.0 \pm 1.56$ & $2.82 \pm 0.66$ & $0.46 \pm 0.12$ & $6.00 \pm 5.16$ & $22.0 \pm 12.50$ \\
\hline \multicolumn{8}{|c|}{ Secondary data for water kiosks (Between 2004-2007, before DMM) } \\
\hline Nyalenda & & 8.15 & 39.87 & 9.94 & 0.09 & $215.25 \pm 1442.4$ & $729.54 \pm 2594.4$ \\
\hline Manyatta & & 6.32 & 16.61 & 5.13 & 0.051 & 402.75 & 1097.2 \\
\hline
\end{tabular}

\subsubsection{Physicochemical water parameters}

The mean values of the physicochemical water quality which is referred to as the suitability or aesthetic characteristics of drinking water, were investigated using turbidity, temperature, $\mathrm{pH}$, total residual chlorine as presented in Table 1.

\subsubsection{Water pH}

The mean values of the $\mathrm{pH}$ observed in Nyalenda water Kiosks was $7.31(S D=0.33)$, with range of 6.71- 8.03, while in Manyatta, the mean value observed was $7.19(S D=0.04)$. The $\mathrm{pH}$ of water samples from Manyatta Kiosks ranged from a minimum of 7.10 to a maximum of 7.24 .

The secondary data before the DMM at the laboratory, indicated that the $\mathrm{pH}$ in Nyalenda was at 8.15 while in Manyatta was at 6.32 . This indicated that the $\mathrm{pH}$ values measured in all the water Kiosks, were in line with the WHO Guideline of $6.5-8.5$.

\subsubsection{Water Turbidity}

The mean turbidity values observed in Nyalenda kiosks was $3.17 \mathrm{NTU}(S D=1.84)$. The turbidity recorded ranged from a minimum of $0.52 \mathrm{NTU}$ to a maximum of $10.80 \mathrm{NTU}$. In Manyatta Kiosks, the mean turbidity observed was $2.82 \mathrm{NTU}(S D=0.66$ with a range of $2.02 \mathrm{NTU}$ to $3.71 \mathrm{NTU}$. The secondary data before the DMM, indicated that, the turbidity in Nyalenda was 9.95 NTU while Manyatta was 5.13 NTU. It was observed that, both the turbidity recorded at the water kiosks and household, were above the WHO guideline value of $1.0 \mathrm{NTU}$, with the samples from Nyalenda kiosks recording the highest turbidity with a mean of 3.17 NTU.

\subsubsection{Residual Chlorine}

The value of residual chlorine observed in the water kiosks were slightly above the recommended WHO of 0.2 $\mathrm{mg} /$ Litre value for both Nyalenda and Manyatta. The mean residual chlorine observed in Nyalenda kiosks was $0.34 \mathrm{mg} / \mathrm{l}(S D=0.18$ with a range of $0.04 \mathrm{mg} / 1$ to $0.68 \mathrm{mg} / \mathrm{l}$. The mean residual chlorine in Manyatta kiosks, was $0.47 \mathrm{mg} / 1(S D=0.12)$ with a range of $0.16 \mathrm{mg} / 1$ to $0.78 \mathrm{mg} / 1$. The secondary data indicated a low level of residual chlorine at the kiosks, with Nyalenda recording $0.09 \mathrm{mg} / \mathrm{l}$ and Manyatta $0.05 \mathrm{mg} / \mathrm{l}$ before the DMM.

\subsubsection{Temperature}

Temperature of the water samples ranged from a minimum of $25.8{ }^{0} \mathrm{C}$ to a maximum of $26.8^{0} \mathrm{C}$. The mean temperature in Nyalenda kiosks observed was $26.03^{\circ} \mathrm{C}(S D=1.73)$ while Manyatta kiosks recorded a mean temperature of $26.0^{\circ} \mathrm{C}(S D=1.56)$.

\subsection{Quality of Drinking Water at the Households}

At the household level in Nyalenda, the mean value for the total coliforms in stored water was $795.46 \mathrm{CFU} / 100 \mathrm{mls}$ $(\mathrm{SD}=2765.68)$. In Manyatta households the mean values for total coliforms in stored water were 12.71CFU/100mls (SD $=9.2)$.

Table 2 indicates that in Nyalenda households the $\mathrm{pH}$ ranged from a Minimum of 6.67 to a maximum of 7.90 with a mean $\mathrm{pH}$ of $6.92(S D=2.01)$. In Manyatta the mean $\mathrm{pH}$ Value was observed at $6.93(S D=0.18)$ and ranged between 6.67 and 7.15 which was within the WHO Guideline. The mean turbidity value recorded for households in Nyalenda was observed at 1.95 NTU $(S D=1.78$ with a range of 6.67 NTU to 6.95 NTU. In Manyatta households, the mean turbidity recorded was $5.12 \mathrm{NTU}(S D=5.82)$. The mean Turbidity recorded at all sample points were however above the WHO guideline value of 1.0 NTU.

The mean residual Chlorine levels in Nyalenda households was $0.18 \mathrm{mg} /$ litre $(S D=0.09$ with a range of $0.00 \mathrm{mg} / 1$ to $0.42 \mathrm{mg} / 1$ while in Manyatta households, the mean was $0.24 \mathrm{mg} / 1(S D=0.16)$. range of $0.08 \mathrm{mg} / 1$ to $0.53 \mathrm{mg} / \mathrm{l}$ which were slightly above the recommended WHO guideline value of $0.2 \mathrm{mg} / \mathrm{l}$. With a $\mathrm{p}=0.003$ in Nyalenda and $p=0.006$ in Manyatta, the mean differences observed were significantly lower in the households as compared to the water kiosks in both areas. In Nyalenda households, $16.46(\mathrm{SD}=252)$ faecal Coliforms were detected while faecal Coliforms in Manyatta households were 20.75CFU/100mls (SD = 409.58). 
Table 2: Quality of drinking water at Households

\begin{tabular}{|l|l|l|l|l|l|l|l|}
\hline & $\begin{array}{l}\text { Number } \\
\text { of } \\
\text { samples }\end{array}$ & $\mathbf{p H}$ & Temperature & Turbidity & $\begin{array}{l}\text { Residual } \\
\text { chlorine }\end{array}$ & $\begin{array}{l}\text { Faecal. } \\
\text { Coliforms }\end{array}$ & $\begin{array}{l}\text { Total } \\
\text { coliforms }\end{array}$ \\
\cline { 3 - 7 } & & ${ }^{\mathbf{0}} \mathbf{C}$ & NTU & $\mathbf{m g} / \mathbf{L}$ & $\begin{array}{l}\text { CFU/100 } \\
\text { mL }\end{array}$ & CFU/100 mL \\
\hline $\begin{array}{l}\text { WHO } \\
\text { value }\end{array}$ & & $\mathbf{6 . 5 - 8 . 5}$ & $\mathbf{2 5}^{\mathbf{0}} \mathbf{C}-\mathbf{3 0}^{\mathbf{0}} \mathbf{C}$ & $\mathbf{1}$ & $\mathbf{0 . 2}$ & $\mathbf{0}$ & $\mathbf{0}$ \\
\hline Nyalenda & 14 & $6.92 \pm 2.01$ & $23.93 \pm 7.1$ & $1.95 \pm 1.78$ & $0.18 \pm 0.1$ & $16.46 \pm 15.9$ & $795.46 \pm 2765.7$ \\
\hline Manyatta & 10 & $6.93 \pm 0.18$ & $10.15 \pm 13.14$ & $5.12 \pm 5.82$ & $0.24 \pm 0.2$ & $20.75 \pm 20.34$ & $12.71 \pm 9.2$ \\
\hline
\end{tabular}

\section{Discussion}

The DMM is a model adopted by water utilities through partnership with community members to improve supply of quality water to residents in informal settlements (World Bank, 2010). The water supplied to the two informal settlements during the study period indicated both at the supply points and at the household level. The findings both from the water kiosks and the households, indicate that the PH value for the two study areas were in line with the WHO guideline of $6.5-8.5$ (WHO, 2010). Though vital, the PH does not have direct impact on consumers' health (Geldreich, Kumpel \& Nelson, 2011). However it is important to note that disinfectants like chlorine are dependent on the water PH for its effectiveness. Water turbidity for both Nyalenda and Manyatta were however higher than 1.0 NTU as recommended by WHO. Turbidity which reflects suspended particles in water, does not pose a direct threat to health but these particles compromises water disinfection due to its shielding effect, thus enhancing the growth and regrowth of microorganism (Boakye-Ansah, 2015). Furthermore, suspended solid particles are an indicator of the presence of contaminants that affect health negatively (Alomran, 2015).

The residual chlorine at the water kiosks was higher than $0.2 \mathrm{mg} / \mathrm{l}$. However, water was still contaminated despite these levels of chlorine. For effective water disinfection, a residual chlorine levels of $>0.5 \mathrm{mg} / 1$ is recommended at a $\mathrm{PH}>8.0$. The presence of fecal coliforms and total coliforms, was attributed to the high turbidity (WHO, 2017), providing shielding effect, barring disinfection of water. The high levels of total coliforms of 830.61 CFU/100ML and 22.00 CFU/100ML and fecal coliforms of 250.97CFU/100ML and 6.00CFU/ML detected, poses a great risk to health.

Notable disparities in temperatures was recorded in the study areas and this was attributed to the tropical hot weather conditions at the time of sample collection, typical of the region. High temperature is prime to the acceleration in the growth of microorganisms. Nevertheless, it's important to keep the temperatures of drinking water below $20^{\circ} \mathrm{C}$. At these levels, some bacteria are not harmful and do not multiply (WHO, 2011; Alomran, 2015).

At the household level, the water PH was within WHO recommendations of 6.5-8.5. The mean difference in the PH was not significant $(\mathrm{p}=0.093)$. The turbidity on the other hand at the household level was still above the recommended WHO guideline, though it declined compared with the water kiosks, with no significant difference $(\mathrm{p}=0.067)$. The mean turbidity ranged from 2.53 NTU to 8.44 NTU with Manyatta household recording a maximum turbidity of 20.00 NTU. This was majorly attributed to the settling of sediments at the household storage.

There was a noted significant decline in residual chlorine at the household level compared with the kiosks $(\mathrm{p}=0.03)$. However contamination of water was still evident with total coliforms detected at a mean of 21.33CFU/100ML in Manyatta and 609.76 CFU/100 ML in Nyalenda while the fecal coliforms ranged from 10.67 CFU/100ML in Manyatta and 18.92 in Nyalenda. High turbidity levels above the WHO recommendations and a significant decrease in the levels of chlorine at the household levels was attributed to the presence of both total and fecal coliforms.

\section{Conclusion}

In conclusion though the DMM model of water supply in Nyalenda and Manyatta has improved access to water in the two informal settlements, the alterations in water quality parameters of drinking water both at the water kiosks and at the household level indicates contamination in the water supply. Results indicated differences between the means in turbidity, total and faecal coliforms from the water Kiosks and from the household. Even though contamination at the Kiosks seemed higher than the household, a two sample t-test indicated that there was no significant difference between the water Kiosk and the household in the two study areas. This means that the water that is stored in the house is already contaminated from the point of supply regardless of the storage and handling practices. The residual chlorine at the water kiosks in the two study areas and at the households in Manyatta was higher than $0.2 \mathrm{mg} / \mathrm{l}$, however, water was still contaminated despite these levels of chlorine.

\section{Recommendations}

A lot of focus need to be put in monitoring the water supplied at the Supply point (water kiosks) due to the findings indicating high bacteriological contamination. The level of bacteriological contamination at the supply points calls 
for close monitoring with regular random sampling of water not only at specific water Kiosks. Monitoring of water should not only be done at the water kiosks but also at the household level. This should be done in collaboration with the Ministry of Health team and the County Health management team. There is need for Health education at household level, in order to improve household practices in the handling and storage of water. This will help reduce water contamination.

\section{References}

Alomran, A. B. (2015). Drinking Water Quality assessment \& water Quality Index of Riyadh, Saudi Arabia. Water Quality Research Journal of Canada.

Boakye-Ansah, A. S. (April 2015). Inequalities in drinking water quality in urban areas. Netherlands: UNESCOIHE.

Citizen Report Card. (2007). Citizen Report Card on Urban Water, Sanitation and Solid Waste Services in Kenya: Summary of Results from Nairobi,Kisumu and Mombasa. Nairobi: CRC Initiative.

Geldreich, E., Kumpel \& Nelson. (2011). Microbial Quality of water supply in Distribution systems. Lewish Publishers,Boca Raton.

Kenya Open Data Project. (2012). Kenya Census. Nairobi.

Nodalis Conseil. ((2014). Kisumu ISUD - Plan - part 1a. Kisumu: Agence Francaise de Development.

United Nations Enviroment Program. (2015). Inited Nations Enviroment Program:Annual Report. New York: UNEP.

Wagah, G. G., Onyango, G. M., \& Kibwage, J. K. (2010). Accessibility of Water Services in Kisumu municipality,Kenya. Journal of Geography and Regional Planning.

WHO. (2011). Guideline for drinking water quality. Geneva: ISBN.

WHO. (2017). Progress on Drinking water Sanitation and Hygiene Update and SDG Baselines. Geneva: WHO.

WHO,UNICEF. (2000). Global Water Supply and Sanitation Assessment 2000 Report. Geneva: WHO,UNICEF.

WHO,UNICEF. (2012). Progress on Sanitation and Drinking Water. Geneva: WHO,UNICEF.

Willems, R. C., \& McDonald, S. A. (2011). Access to Safe Drinking Water:A Low Income Sustainable Water Purification System. Global Majority E-Journal, 304-316.

World Bank. (2010). Reforming Infrastructure: Privatization, Regulation and Competition World Bank Policy Research Report. Washington DC: World Bank: World Bank.

World Health Organization. (2010). WHO/UNICEF jOINT Monitoring report 2010. Geneva: WHO.

WSP Water and Sanitation Program. ( 2009). Improving Water Utility Services through Delegated Management Lessons from the Utility and Small Scale providers in Kisumu, Kenya. Nairobi: WSP. 